\title{
Engaging the Family in Recovery: Outcomes of a Community-Based Family Intervention
}

\author{
Katrine S. Bunagan \\ Chantal Ellis S. Tabo \\ Ateneo de Manila University \\ Violeta V. Bautista \\ University of the Philippines \\ Maria Isabel E. Melgar \\ Trixia Anne C. Co \\ Maria Regina H. Hechanova \\ Ateneo de Manila University
}

\begin{abstract}
The Katatagan Kontra Droga para sa Komunidad (KKDK) is a Filipino community-based drug recovery program that addresses individual and family issues. This study explores the changes in the family after the drug users completed the program. Surveys and interviews were used to evaluate changes in family support, quality of family life, and substance use disorder (SUD) symptoms. Results show participants perceived significant increase in family support and quality of family life, as well as decrease in SUD symptoms. Their family members also reported individual and familial changes in the participants as a result of the program. They showed remorse, became more responsible, and communicated better after going through the intervention. There was also an improvement in quality of family life, religious rituals, and time spent with the family. Implications on community-based drug recovery programs focusing on family changes are discussed.
\end{abstract}

Keywords: family, community, drug recovery program

Correspondence regarding this article may be directed to: Katrine S. Bunagan, Department of Psychology, Ateneo de Manila University, Quezon City. Email: kbunagan@ateneo.edu 
Studies on drug use and family factors found that families dealing with drug use often have complex dynamics and that the relationship between drug and family dynamics appears to be bidirectional (Hosseinbor, Bakhshani, \& Shakiba, 2012). Literature shows that parenting styles impact onset and course of drug use in minors (Gruber \& Taylor, 2006). Having drug-abusing parents affected children's outcomes. Likewise, patterns of neglectful or inconsistent parenting result in less favorable outcomes for children, especially those raised in so called substance use disorder (SUD) families (Lander, Howsare, \& Byrne, 2013).

Even as family factors are associated with drug use, the family is also a significant contributor to recovery capital. Family plays an important role in drug recovery and intervention (Coleman \& Davis, 1978; Stanton \& Shadish, 1997; Velleman, Templeton, \& Copello, 2005). Research shows that interventions that include the family have a higher chance of success than interventions without addressing family problems (Stanton \& Shadish, 1997). Family support is an important contributor to drug recovery, so much so that people without family support are at a disadvantage in formal drug use treatment (Clark, 2001). Many drug users who go through addiction recovery programs relapse back to drug use because the program has not adequately addressed the important role of the family (Lavee \& Altus, 2001).

Literature on drug recovery in the Philippines is sparse. There is some literature on the recovery of users (Guabong, Longno, Castro \& Guinto, 2014), predictors of relapse (Tuliao \& Liwag, 2011) and effect of drug use on children (Yusay \& Canoy, 2019). However, there is a dearth on literature on the involvement of families in drug recovery interventions in the Philippines. This study contributes to the gap by examining the outcomes of a community-based drug recovery intervention that includes family members.

\section{Family, Drug Use and Recovery}

Contemporary perspectives on drug use recognize that it is a complex issue with biological, psychological, personality, cognitive, social, cultural and environmental influences (Skewes \& Gonzalez, 2013). Among various influences, the family plays a large role both in 
the use and recovery of a person who uses drugs (PWUDs).

Research suggests family-related factors that may influence drug use. Factors such as maladaptive interaction patterns, poor family management, weak family ties, dysfunctional authority structures, and family history of drug use have been identified as among the contributory factors to drug addiction for adults and adolescents (Hawkins, Catalano, \& Miller, 1992; Jêdrzejczak, 2005; Szapocnik et al., 1989 ).

However, the family can also be a source of recovery capital among PWUDs. Studies show that when relationship in the family is more encouraging and supportive, individuals have healthier coping mechanisms in the face of challenges (Goldenberg \& Goldenberg, 2013). Thus, mobilizing the resources of the family enhances the effectiveness of a drug recovery program (Clark, 2001; Stanton \& Shadish, 1997; Velleman et al., 2005).

The recognition of the important role family plays in recovery suggests the need to involve them and there is robust evidence that interventions involving the family are more effective in reducing drug use than those that do not (Lewis, Piercy, Sprenkle, \& Trepper, 1990; Stanton \& Shadish, 1997). The literature on psychotherapy for SUD is replete with studies that show how family therapy using the systems approach is more effective in facilitating drug recovery and preventing relapse (Daley, 2013; Goldenberg \& Goldenberg, 2013; Larner, 2004; Stanton \& Shadish, 1997). Systemic therapy aims to cultivate family support and functioning by addressing past, present, and future relationships within the family with the goal of changing family functioning (Goldenberg \& Goldenberg, 2013; Larner, 2004).

\section{Community Based Mental Health Interventions in the Philippines}

Much of the literature on family interventions has been in the context of family psychotherapy. However, recent years have seen a rise in outpatient and community-based programs for drug use. In community-based programs, community workers reach out to families and families, in turn, become more involved as well in the community (Carter \& McGoldrick, 1999). An integrated family and community 
program has been shown to play a role in maximizing the effectiveness of prevention and recovery programs for individuals with SUDs. In particular, utilizing community workers is an innovative and costeffective means to deliver mental health programs and interventions for individuals and their families. This approach is considered as one of the best practices to address mental health in large-scale programs (Rebello, Marques, Gureje, \& Pike, 2014; Vaughan, Kok, Witter, \& Dieleman, 2015).

The use of community-based family interventions in the Philippines is still in its infancy. A study on Katatagan, a groupbased resilience intervention for Filipino disaster survivors, reports significant improvements in anxiety and resilience compared to those who did not go through the program (Hechanova, Waelde, \& Ramos, 2016). Parr (2015) documented the use of expressive arts in a family intervention delivered to families in Tacloban who survived Typhoon Haiyan. A family intervention entitled Masayang Pamilya, was also developed and pilot-tested among low-income recipients of the conditional cash transfer program of the Department of Social Work and Development. The program tackles emotions, mindfulness techniques, collaborative problem-solving and parenting experiences within small groups to improve well-being and prevent childmaltreatment (Alampay et al., 2018).

\section{Development of KKDK and its Family Support Component}

To date, there has been no documented community-based drug treatment program where families are active participants in the intervention. This is unfortunate because a needs analysis conducted among PWUDs and their families highlight the critical role of family. Interviews revealed the existence of a number of family-related issues including drug use in the family, family problems and separation, parental neglect and abuse, dysfunctional parenting, etc. At the same time, family members did not have knowledge on the effects and symptoms of drug use and how to help their family members (PAP, 2017). Beyond family issues, the needs analysis highlighted the lack of knowledge among PWUDs on how to manage their cravings, triggers to avoid, and how to avoid relapse. At the same time, drug use was a 
maladaptive way of coping with their many problems. They reported that their drug use led to more problems in their family such as conflict and separation (Hechanova et al., 2018).

The Katatagan Kontra Droga sa Komunidad (KKDK) was designed to address the psychosocial needs of mild-risk users. The KKDK intervention consisted of 12 individual modules that focused on skills for recovery (motivation to change, managing cravings, managing triggers, refusal skills, healthy lifestyle) as well as life skills (managing negative emotions, interpersonal skills, problem-solving, stress management). These modules were designed to be culturally appropriate to the Philippine context, but used as its foundation principles of motivational interviewing, cognitive behavioral therapy, and mindfulness (for more information on KKDK, see Hechanova et al., 2019).

The families were engaged in the treatment in two ways. The first was through the homework embedded in individual modules that required participants to involve their family members. Some examples of assignments included asking family members about the effects of their drug use on them, finding out how important it is to family members that participants change their drug use behaviors, discussing with family members factors that triggers use, and asking for forgiveness for hurts they may have caused, etc.

Beyond engaging the family in the homework, three family intervention modules were developed. The family modules used family systems as a framework that emphasizes the importance of understanding dynamics within the family to facilitate changes that could support clients in their drug recovery journey. The modules aimed to facilitate communication among family members about (i) the nature of the relative's drug use; (ii) how the drug use is affecting the family; (iii) specific aspects of family relationship that contribute to drug use; (iv) support from the family to the drug user; and (v) useful strategies in dealing with identified family-related problems. The development of modules were guided by the systemic family therapy theory and by family addictions recovery programs in the context of a residential treatment facility (PAP, 2017). 
The first KKDK Family module is Paglilinaw at Pag-unawa sa Problemang Dulot ng Adiksyon (Knowing and Understanding the Problems Brought by Addiction). In this module, only the family members are present, not the drug user. This module allows the participants to share their thoughts and feelings about the family member who uses drugs, and addresses misconceptions by clarifying what addiction does to a person. Part of the aim is to help family members reflect on the effect of drugs on the family and the roots of addiction. This module takes approximately 2 hours and 30 minutes to complete (PAP, 2017).

The second module is Pagharap sa Ugat ng Adiksyon (Facing the Root of Addiction), where both family members and drug users are required to attend. This module facilitates dialogue between the parties as each member is given an opportunity to share their experiences vis-a-vis drug addiction. It also aims to address the root of the problem by determining what triggered the start of the drug use. It provides an opportunity for the family to open communication lines regarding drug use and move them towards the planning phase in the next module. This module takes approximately 3 hours and 5 minutes to complete (PAP, 2017).

Finally, the third module is Paghakbang sa Pamilyang Bumabangon (Moving Forward as a Family in Recovery). Based on what they learned about the roots of addiction from the previous modules, participants and family members are asked to make plans for recovery and change in both individual and family functioning to support recovery. This module takes approximately 3 hours and 10 minutes to complete.

KKDK was pilot-tested and initial evaluations revealed significant improvements in recovery skills, life skills, and psychological wellbeing of participants. An analysis of posttest scores also revealed a negative correlation between life skills and SUD symptoms and a positive relationship between recovery skills and psychological wellbeing (Hechanova et al., 2019). However, the aforementioned study did not report any outcomes related to the family. This study complements the study of Hechanova et al. (2019) by highlighting the outcomes of the KKDK interventions on the family of participants. 


\section{Research Question}

This study examined the outcomes of the KKDK interventions on the families of participants. Given the goal of systemic therapy to build family support and enhance functioning by improving relationships within the family (Goldenberg \& Goldenberg, 2013; Larner, 2004), it was expected that enhancing recovery and life skills would enable greater family support and, subsequently, improve family functioning.

More specifically, the study sought to answer the following questions:

1) What are the perceived changes in participants and family relationships as a result of the program?

2) Can the program enhance perceived family support and family functioning?

3) What is the relationship between family support and family functioning and SUD symptoms at the end of the program?

\section{METHOD}

\section{Design}

This study utilized a mixed method design to gain a better understanding of the outcomes of the program on the participants and their families. This triangulation design uses quantitative and qualitative data simultaneously to use one form of evidence to complement the other and thus obtain a clearer understanding of the developing experiences within participating families.

A pretest-posttest design for the quantitative evaluation of the KKDK family modules was conducted. Post-program evaluation was also done qualitatively using semistructured interviews with family members who participated in the program.

\section{Setting}

Seven communities in two Metro Manila cities were tapped for the study. The KKDK program for individual modules and family modules were conducted by trained community workers in barangay halls (for 
individual modules) and a school hall (for family modules).

\section{Sample}

Participants in two Metro Manila cities were identified in coordination with their respective City Vice Mayor's Office. The barangay captains and their corresponding precincts helped with the identification and recruitment of participants. The sample is composed of a random mix of male, female, and LGBTQ participants. Many had undergone other community-based interventions that tapped into livelihood (BANAT) and spirituality (SIPAG and Sanlakbay) aspects of addictions recovery work. BANAT provides opportunities for work, while SIPAG and Sanlakbay are programs focused on prayer and developing spirituality towards recovery.

Participants in the family modules were family relatives of drug users who participated in the KKDK modules. Family members included parents, siblings, spouses, children, relatives or close friends. The number of family members attending for each participant varied.

A total of 107 KKDK participants who joined the family modules participated in the survey while 19 family participants were interviewed. The age range of the family members who attended are from 16 to 75 years. Majority of them were wives, children, and husbands of the KKDK participants. A small number were parents, siblings, and close friends.

Family interviewees were selected through convenience and purposive sampling for an individualized face-to-face interview by the research team. Interviewees met the inclusion criteria that they had to be family members of KKDK participants who finished the program, attended the family modules, and at least 16 years old. Of the 19 participants, nine were children of participants (four daughters and two sons), eight were wives, one sister, and one mother. Their ages ranged from 16 to 75 years.

\section{Measures}

Interview guide. For the qualitative aspect, a semistructured interview guide was conducted in Filipino for collecting data with 
the family members who attended the KKDK family modules. The interview included questions about how family members view the family modules that they attended, and what changes they saw in their family after the program. The main questions were: "How do you view the KKDK program?" and "How did undergoing the program affect you/your family?"

Family support. This measures how an individual perceives social support from their family. This study used the Filipino translated Multidimensional Scale of Perceived Social Support by Zimet, Dahlem, Zimet, and Farley (1988). Items were rated on a 7-point Likert scale where 7 is Very Strongly Agree and 1 is Very Strongly Disagree. As the measure is part of a battery of tests for the drug user, the researchers only included the items from the family factor. A sample item is "I can talk about my problems with my family." The test had Cronbach's alphas of .88 at pretest and .87 at posttest, indicating internal consistency.

Family functioning. This study used the Filipino translated GF12 (General Functioning) subscale of the Family Assessment Device (FAD) by Epstein, Baldwin, and Bishop (1983) to measure family functioning. Based on McMaster's model of family functioning (Epstein, Bishop, \& Levine, 1978), it measures six dimensions of family life. For this study, only the 12-item scale that measures the family's general functioning was utilized (Boterhoven de Haan, Hafekost, Lawrence, Sawyer, \& Zubrick, 2015; Turliuc, Ciudin, \& Roby, 2016). It has a 4-point Likert scale, such that the higher the score, the more they perceive their family as problematic. Sample items include "Planning family activities is difficult because we misunderstand each other" and "There are a lot of bad feelings in the family." The GF subscale had adequate internal consistency with Cronbach's alphas of .82 at pretest and .78 at posttest.

Substance use dependence. This refers to symptoms of SUD based on ICD-10. It was measured using the ICD-10 checklist for mental disorders (psychoactive substance use syndromes module), a selfreport checklist to indicate whether or not they experienced cravings, withdrawal, harmful effects, etc. Internal consistency reliability was .67 for pretest and .72 for posttest. 


\section{Procedure}

Inviting families. Families of participating drug users were invited to join the Family Modules sessions. Community facilitators and barangay coordinators encouraged participants to bring their families to attend the family modules as part of the KKDK program. They were instructed to bring at least one family member. Majority of participants were able to bring a family member to the family modules. Challenges with attendance include difficulties with finding childcare, needing to work on the designated schedule, and being estranged from family members.

Running the family modules. The family modules were run by trained community workers working side by side with KKDK facilitators from PAP. The modules were run after the 12 individual modules. This is to ensure that the drug users already have processed much of their drug use experience, and has had some time to reflect on what they want to do in life. In this way, it is expected that they are more ready to engage their respective families in meaningful facilitated sharing sessions. The family modules were run once a week for three weeks.

Administering the surveys. Participants were asked to complete a pretest prior to the first KKDK module. A posttest evaluation was also given on the third and last family module. After the closing ceremony of the module, the participants were requested to answer the same scale as the survey in the first individual module. All participants read and signed informed consent forms to participate in the research.

Interviewing the families. Family participants who were willing to be interviewed read and filled out informed consent forms with an overview of the research project. It emphasized that their involvement in the research was voluntary. They were also given a short briefing that discussed that the research project is an independent endeavor of the PAP and that their answers were strictly confidential. The interview phase occurred a week after all the family modules have been conducted. These interviews were conducted for about 30-45 minutes per family member. Inclusion criteria for the interviewees had to be met and informed consent forms read and signed. 


\section{Ethical Procedures}

Ethical clearance for this study was obtained from the Ateneo de Manila University research ethics board. Care was made to follow the principle of informed consent and beneficence. The program promoted values of respect for rights and dignity of participants, facilitators, and stakeholders, both in the design and how it was facilitated. Reflexivity was practiced by the researchers, especially in conducting thematic analysis of qualitative data, cognizant of potential personal and institutional biases. Due caution was practiced in interpretation and interrater consultations were undertaken in coming up with themes. Consensus for the final categories and sub-categories was obtained.

\section{Data Analysis}

Thematic analysis was used to extract the themes from individual interviews after the last family module. Thematic analysis was used to examine the data collected from the interviews, narratives, and records of the participants (Creswell, 2009). The phases of thematic analysis outlined by Braun and Clarke (2006) were used to process the data. Phase One involved familiarizing with the data and transcribing the interviews. Phase Two was for identifying ideas that are potentially interesting from the data set and an initial set of codes were generated by three of the researchers. Phase Three involved examination and clustering of the different codes from Phase Two. Potential themes and subthemes were culled and discussed in a meeting with the research team. After reaching a consensus, themes were consolidated and finalized.

To analyze the pretest-posttest evaluation, a paired samples t-test was employed using IBM Statistical Package for Social Sciences (SPSS) version 21 software. This statistical tool helped determine if there were significant changes in the perceived family support, family functioning, and SUD symptoms by the former drug users before and after the family modules. Incomplete data were excluded from the analysis. 


\section{RESULTS}

\section{Changes Observed by Participants and Their Family Members}

Four weeks after the conclusion of the KKDK program, the family members were interviewed about the changes they have observed and three themes emerged: being responsible, asserting thoughts and feelings, and asking for forgiveness/reconciliation.

In the 19 interviews, three themes surfaced frequently regarding changes in individual characteristics among the former drug users, as observed by family members. They were perceived as being more responsible, asserting their thoughts and feelings, and asking for forgiveness for past transgressions.

Being responsible. Family members shared how they observed the former drug users to behave more responsibly in performing their domestic roles. As parents, they showed more involvement in their children's school work and obligations. They helped with the assignments and attended parent-teacher conferences. Their parenting styles also seemed to change. One father allowed his child to play outside with the neighbors for a certain time without resorting to scolding. As partners, the former drug users were also observed to help more around the house. Partners mentioned how they now cook, clean the house, and even help with laundry.

Hindi na niya nagagawa. Andyan pa din yung pagkaayos ng bahay niya. Maasikaso pa rin. Nagluluto. Naglalaba, tinutulungan na ko maglaba. Dati wala eh. Kahit maglaba ko dyan, wala eh, tulog siya. [He takes care of things now. He cooks, does the laundry, helps me now with the laundry. Before, there was none of that. When I did the laundry, he would just be asleep.] (Wife)

Related to this, family members also observed how their family members seemed to have shifted their attitude towards money. Before the program, they had little to no savings because the money they earned was spent on vices. After going through the program, the family members shared how the recovering drug users saved money 
for the family, such as for children's allowance and more important expenditures. They also refrained from asking money from their partners.

Ngayon? Ayun, ano lang siya tutok na siya sa ano, sa pagdadrive niya. Tapos pati baon ko nagbibigay na niya ng sapat, hindi katulad ng dati na hindi na ako madalas nabibigyan ng baon. [Now, he is focused on his driving. He is also able to give me adequate allowance. Unlike before, he often could not give me any allowance.] (Child)

Asserting thoughts and feelings. Some improvements in the interpersonal communication style of the former drug users were also observed. They tended to talk more about their problems without hesitation. They had more effective ways of talking to each other, even when they would argue. Family members also learned how to communicate effectively. They were firmer with their beliefs and less afraid to fight for what they think is right.

Oo nakokontrol niya yung bibig niya ngayon dati palaaway si ate. Panganay namin yan tas dalawang lalaki. Talagang mabunganga siya noon pag may nakita siyang hindi niya kagustuhan tatatatatatata ganyan na yung bibig niya ngayon nakakapag control kahit papano natuto narin siya makinig sa nanay namin. [She is now able to control the things that she says. She used to always pick fights. She is our eldest, then our two brothers. She used to be loudmouthed when she sees something she does not like. Now she is able to control what comes out of her mouth, she has learned to listen to our mother.] (Sister)

The former drug users were also observed to be more able to express their love, as the family members observed that they are more affectionate. They openly said, "I love you," and showed signs of affection more frequently than before. They were also more likely to admit their shortcomings and take actions to change.

Tapos yung mga bagay na simple lang na syempre po bilang asawa natutuwa ako. Yung bang kahit- sabihin niya "I love you." Yung bago matulog po na sa- dati hindi niya ginagawa sakin. Opo, totoo po yan. Kahit po itanong niyo sa kanya. Talagang 
malaking-malaki pinagbago niya. [Those simple things that make a wife happy. Even just him saying, "I love you." Before going to sleep... he did not used to do that before. What I'm saying is true, ask him. He really changed so much.] (Wife)

Asking for forgiveness/reconciliation. Recovering users also reportedly showed remorse over their past problematic behaviors and asked for forgiveness, which was very much appreciated by their family members. The drug users' relationships with their relatives improved particularly when the latter noticed positive changes in their behavior. Mutual trust was identified as a key ingredient in healing and drug recovery.

Ano, lalo na yung panganay ko, galit siya sa una sa ama niya dahil nga siyempre nakikita niyang nag-aaway parati, ganun. Pero nung bandang huli na, yun nga na nagbago na yung ama niya, napaliwanagan naman ng ama niya, na humingi din $\mathrm{ng}$ sorry, ayun, na ano din ang ano. Mas lalo nga naging close sila nga ngayon eh. [My eldest, especially, was angry at their father, because they see us fighting all the time. Later on, their father changed, he explained things to them, asked for forgiveness, things got fixed. They are much closer now.] (Wife)

\section{Changes Observed by Participants in Their Family Relationships}

Three themes emerged from the interviews regarding changes in important aspects of family life as a result of the program. These changes include improved quality of family life, the family going through religious rituals together, and spending more time as a family.

Improved family relationships. The family members noted some changes in the family relationship. They reported feeling closer with former drug users as they are more able to talk and bond with one another. This was mentioned by both the partners and children. In one interview, a child admitted how she could not be proud of her father (former drug user) before, but that had changed.

Daughter: Tapos ayun po, super ano malapit na po ako kay Papa

tapos, ano kapag wala po akong ginagawa, lumalapit po ako 
kay papa, sumasama po ako sa byahe niya, kasi po ayun nga. Tapos ano po parang gusto ko nang ipagmalaki tatay ko. Ayon po.

Interviewer: Dati ba hindi?

Daughter: Hindi po talaga eh kasi po ano. Hindi ko po talaga kaya promise sa mga kaibigan ko hindi ko po kayang ipagmalaki ang parents ko kasi nga po ganun po yung bisyo nila. Wala po silang bisyo na sigarilyo, mga alak, pero ayun po talaga eh, yung drugs. [I am now very close to Papa. When I am not doing anything, I approach Papa and go with him on duty. Now, I can be proud of my father. I was not able to do that before. With my friends, I could not be proud of my parents because of their vices. They did not smoke or drink, but did drugs.] (Daughter)

Family members likewise learned how to understand the former drug users. They shared how they were more open with one another. One daughter shared how she felt happy and hopeful that they could better face challenges as a family.

Ano, nag open na kami sa isa't-isa. Tapos ayun ang saya po namin kumakain, sama sama, tapos yung dati na pagsubok ngayon kinakaya namin, nang parents po namin ng family po namin. [We have opened up to each other. We are so happy eating together. Even trials that we go through can be ably tackled, by our parents, by our family.] (Daughter)

Interviewer: Ikaw personal ba na relationship mo sa tatay mo, dati ba close kayo?

Daughter: Hindi po medyo, pero ngayon po, sobrang close po.

Interviewer: Tinutulungan ka na rin sa school? Hinahatid ka niya?

Daughter: Opo. Yung ano po, kapag may meeting siya na po pumupunta hindi na si mama. [We were not that close before, but now, we are very close. He is the one who goes to school meetings now, instead of my mama.] (Daughter)

Religious rituals. Family members noticed how the former drug users in their family became more religious. There were even 
some former users who encouraged their family members to attend Sunday masses together.

Opo, sobra po ng ibang iba. Kasi po dati talagang parang hindi po kami makakapag simba tapos hindi po makakakain ng sabaysabay parang may sarili po kaming mundo. Tapos ngayon po, ngayong pasko nagawa po namin ang gusto naming gawin. [He is very different now. We were not able to go to mass together before, as if existing in a different world. Now, this Christmas, we are able to do the things we want.] (Daughter)

The family also prays more regularly than before. Some wives shared how it is the husband (former drug user) who asks if she already prayed, which was not how it was before.

Mas ano pa siya ngayon sa'kin. Mas ano siya sa espiritual ngayon. Kinakayag niya pa ko. "Simba tayo pag Linggo," sabi niya. Siya pa nagpapa-alala po sakin. Tas bago matulog sabi niya sakin, "Nagdasal ka na ba?" Yung mga ganon po. Ganon siya ngayon. [He is now more spiritual than I am. He tells me, "Let's go to mass on Sundays." He is the one who reminds me. Before going to sleep, he asks, "Have you prayed?" That's how he is now.] (Wife)

More time as a family. Family members shared how the former drug users chose to spend more time with them family compared to their usual group of friends. They recounted that even during Christmas and New Year, they had a happier experience because the family was complete. They also noted how the former drug users were choosing to spend their Sunday as family day, such as going to mass together and going to certain places afterwards.

Masaya, lalo na yung bago lahat nandun ngayon, sama sama po. Dati po kasi pagbabagong taon kami hindi po. Iba po kasi si papa noon yung mga taong gumagamit pa po siya. Madalas mag-away sila ni Mama noong Bagong Taon, pero ngayon hindi $n a$. [Happy, especially being together. We did not use to spend the new year together. Papa was a different person when he was still using. He constantly had fights with Mama on New Year's. But now, not anymore.] (Daughter) 
Furthermore, they shared about how former drug users also insisted on eating dinner together as a family, compared to before when their free time was almost always spent outside the home.

Dati ho talaga, pagka-abot niya ng pera...tambay na yan sa labas...Ngayon pag dumating sa bahay, kakain kami sabaysabay...Kahit na alas-singko palangm nasa loob nalang po siya ng bahay, nanunuod nalang siya ng tv. Hindi na po siya umaalis.

[Before he would just hand me money and then leave and stay outside. Now, we eat together. These days, even if it is still five pm, he just stays at home and watches TV. He does not leave anymore.]

\section{Changes in Family Functioning, Perceived Family Support, and SUD Symptoms}

Participants who went through the KKDK program reported significant improvements in family support and family functioning. They also had significant decrease in SUD symptoms before and after the program. Table 1 shows a summary of changes in these variables from pretest to posttest.

Family functioning items covered different areas such as acceptance, communication, and decision-making. Significant differences were evident in family functioning items particularly in acceptance (Item 4, $t=3.44$ ) and communication (Item $3, t=2.13$ ). Though one of the three decision-making items (Item 9) and

Table 1. Summary of Family Functioning, Family Support, and SUD Symptoms

\begin{tabular}{lccccc}
\hline & Pretest & Posttest & & & \\
& $M(S D)$ & $M(S D)$ & $t$ & $d f$ & $p$ \\
\hline Family Functioning & $2.96(0.52)$ & $3.29(0.48)$ & 4.5 & 91 & .04 \\
Perceived Social Support & $6.39(0.78)$ & $6.67(0.59)$ & 3.0 & 91 & .03 \\
SUD Symptoms & $0.39(0.71)$ & $0.30(0.75)$ & 1.3 & 91 & .19 \\
\hline
\end{tabular}


communication items (Item 5) did not show a significant difference in their mean scores, other items showed a difference in the paired samples t-test. Overall, results showed a general improvement in family functioning before and after the program, as shown in Table 2.

Participants reported an increase in family support after completing the program. All items had a higher mean score in the posttest than the pretest scores. Statistically, the difference between Items $1(t=2.19)$ and $2(t=2.33)$ in the pretest and posttests were significant at $\alpha=0.05$ level. The difference between item $3(t=4.06)$ in the pretest and posttest on the other hand was significant at $\alpha=0.01$ level. Participants report that their families strive to help them (Item 1), that they receive family support and emotional help (Item 2), and they are able to discuss problems with their family (Item 3). These changes in perceived family support are shown in Table 3.

SUD symptoms, especially experiences of cravings, withdrawal symptoms, and persistent use of substance despite harmful consequences, showed significant decline after participating in the program. Table 4 contains the items that look into SUD symptoms and changes in the experience of symptoms during the course of the program.

\section{DISCUSSION}

Significant changes emerged in family functioning, perceived social support, and SUD symptoms in the KKDK participants. These changes appear consistent with the qualitative changes observed by family members in both the participants and their families. Family support, in particular, seemed to have a significant effect on reducing SUD symptoms, as shown in Table 5 .

Our first research question was what changes were observed by family members. Results revealed changes in the person as well as in the family. Family members noticed changes in the KKDK participant after going through the individual and family modules, particularly in terms of becoming more responsible, ability to assert thoughts and feelings, and asking for forgiveness. Changes in the family were also observed, such as improving family relations, engaging in religious rituals, and spending more time as a family. This is consistent with 


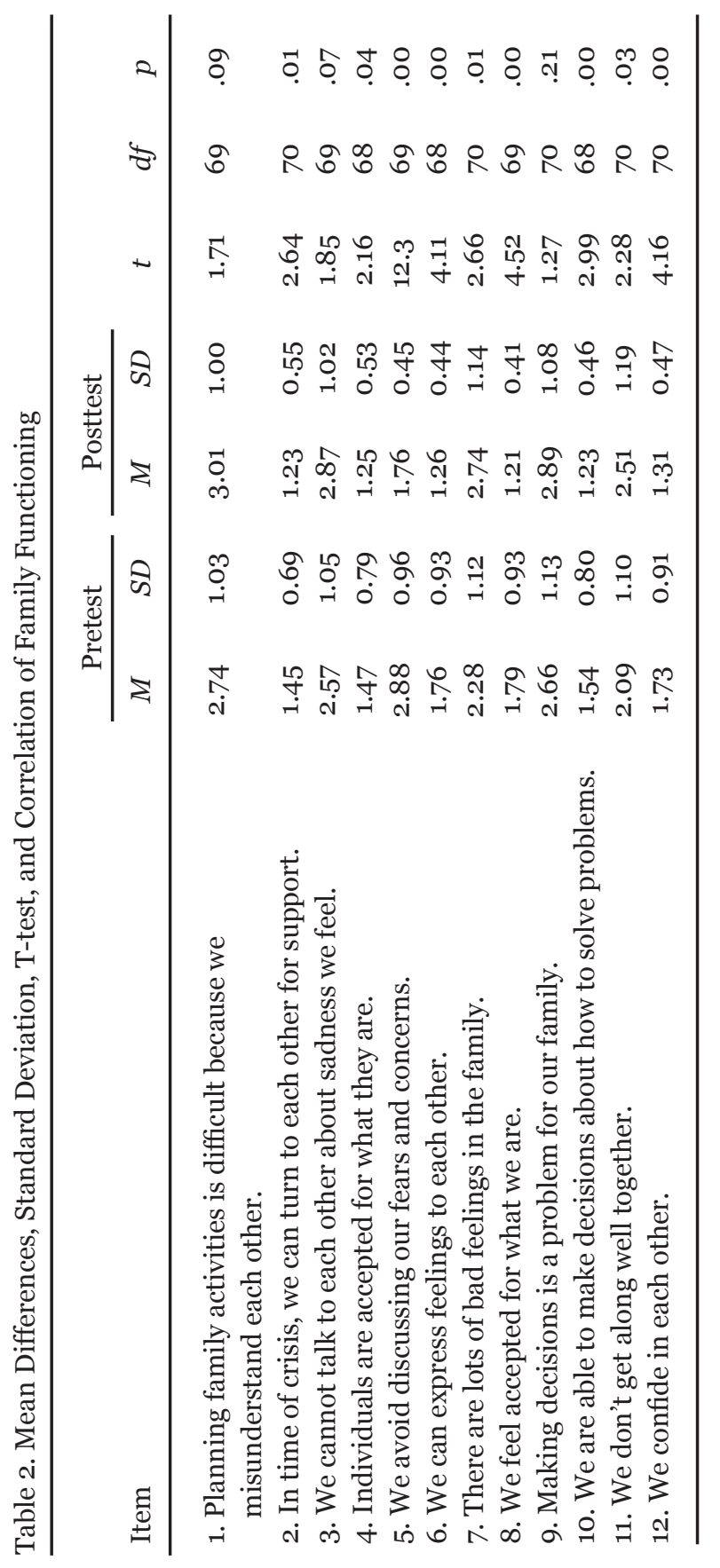




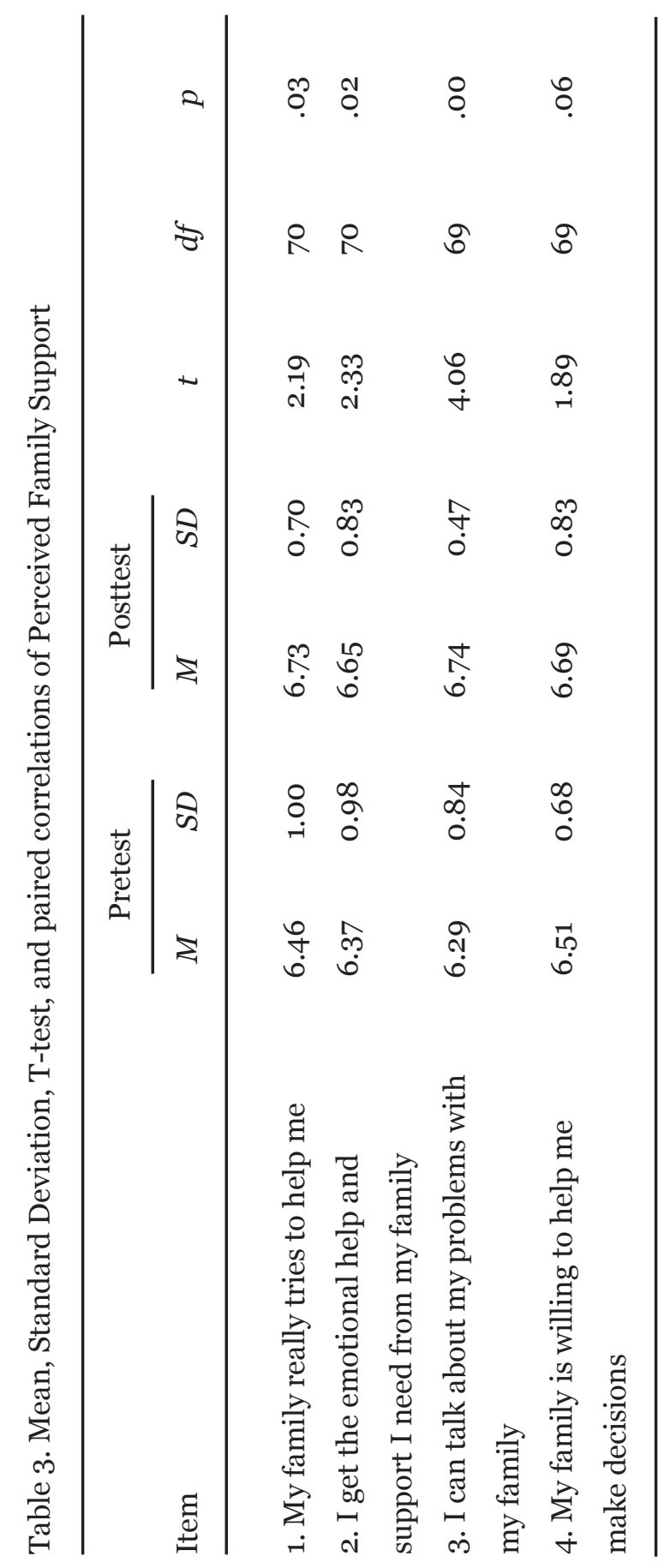




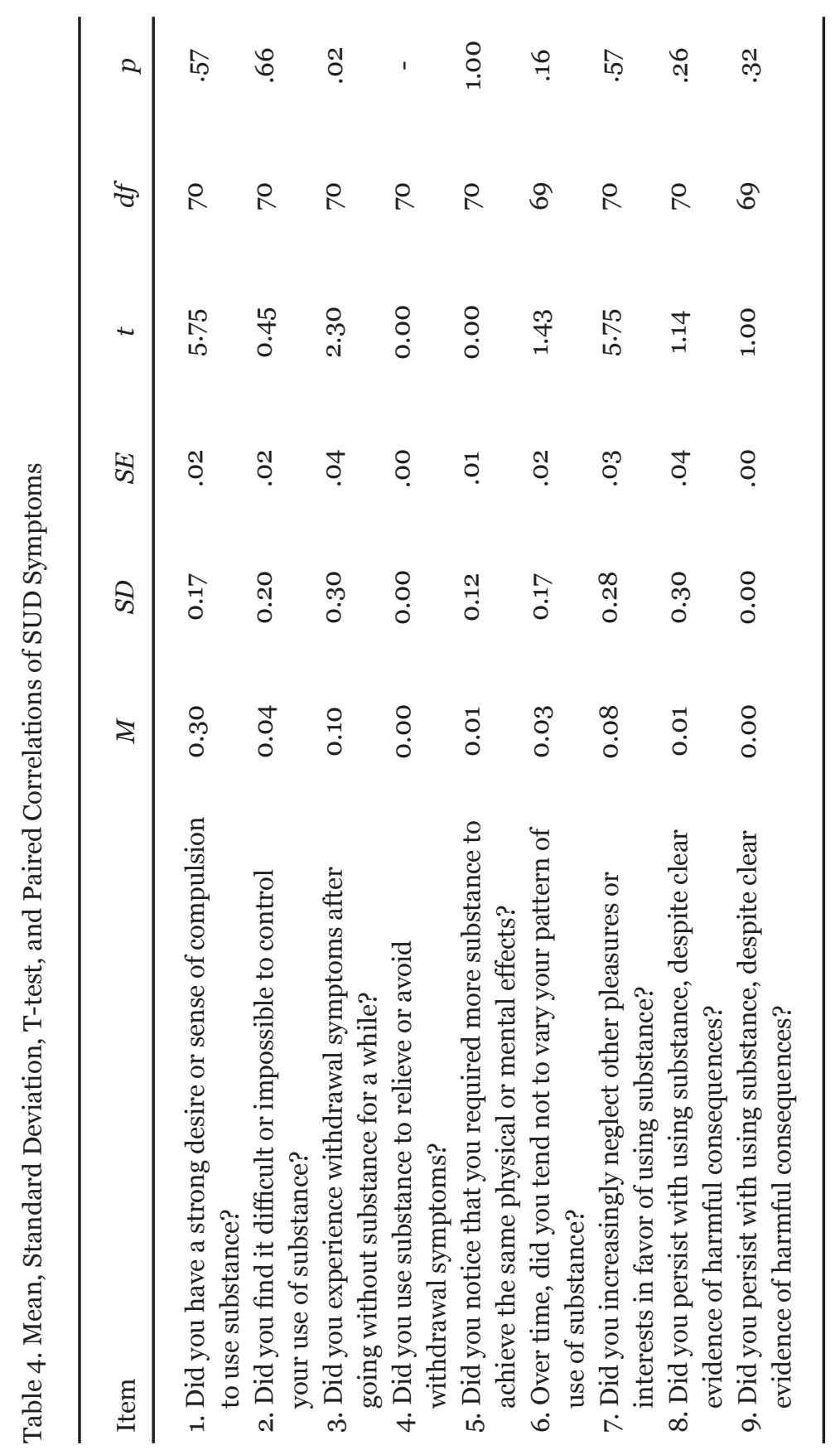




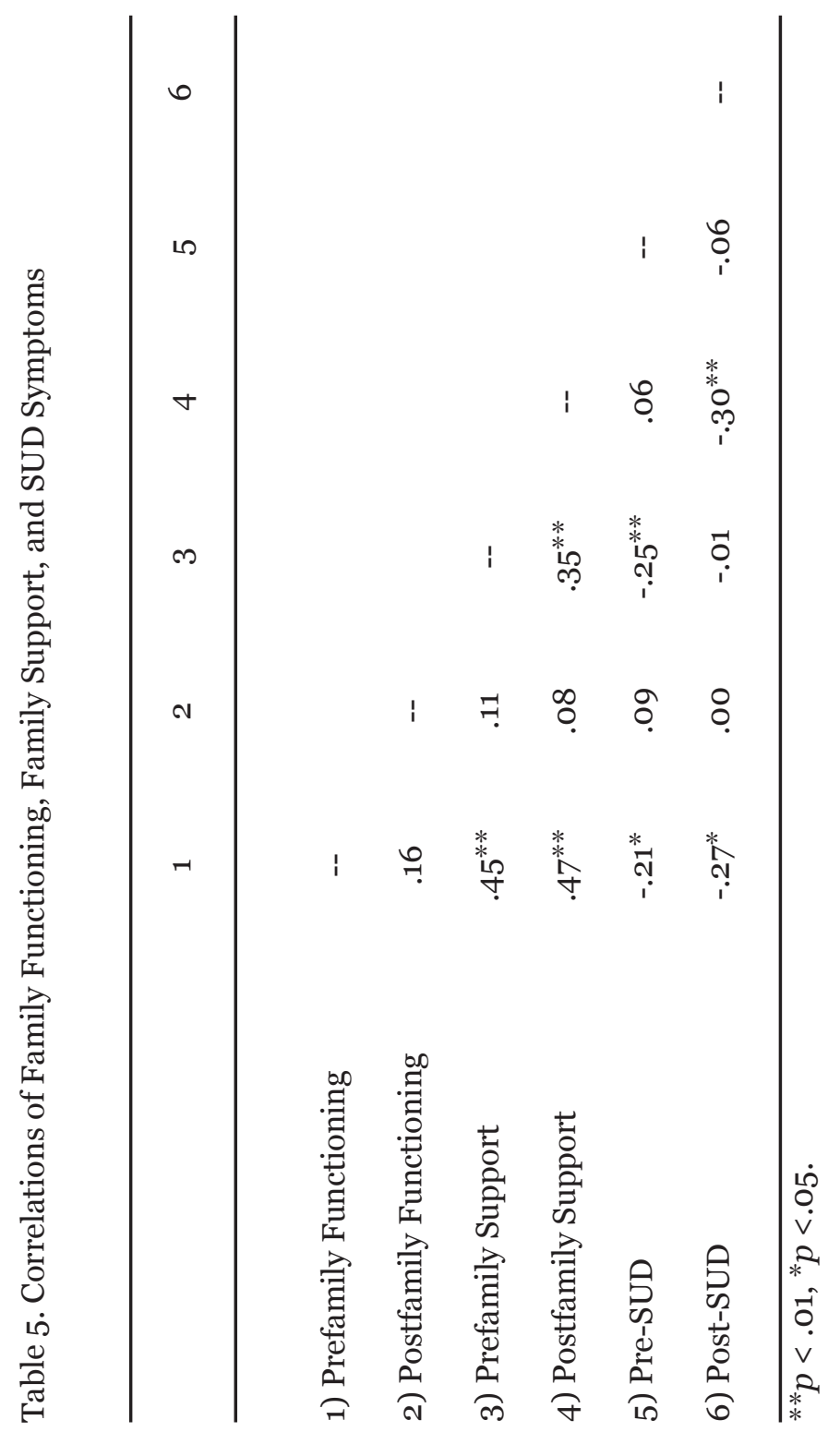


the literature that found more favorable outcomes after engaging in family interventions for substance and alcohol use disorders (Copello, Velleman, \& Templeton, 2005; Stanton \& Shadish, 1997).

In relation to the second research question, perceived family support and family functioning were enhanced after participating in the family intervention, as shown in the qualitative and quantitative data. This is consistent with findings from the literature on familybased interventions that show improvements in family functioning (Rowe, 2012).

The third research question looked into the changes in perceived family support and family functioning and how these changes correspond to decreases in SUD symptoms as participants go through and finish the KKDK individual and family modules. Results highlighted the importance of families taking time out to listen to what their relative has gone through and exploring ways to help the recovering user. This made users feel that their families cared for them, rather than rejecting or blaming them. This validates literature that the sense of being supported by the family can facilitate recovery from drug use (Rowe, 2012).

An important change was the increased time together as a family. This is important especially in view of the fact that long hours of work is increasingly becoming a way of life among Filipinos (Edralin, 2012). Interestingly, the modules were perceived by family members to be linked to observed changes in the quality of interactions within the family. Changes in family well-being has been identified in the literature as a salient factor that protects a person from continuing with drug use (Ibrahim \& Kumar, 2009; Velleman, Templeton, \& Copello, 2005).

Given the religious nature of the Filipino psyche (Miralao, 1997), it is not surprising that family members manifest more healthy family relationships in the form of togetherness in religious rituals. This augurs well for drug users. Studies have recognized the role of religion and spirituality in helping Filipinos survive against the odds, as in the case of survivors of Typhoon Yolanda (Almazan et al., 2018) and drug dependents (Hechanova et al., 2018).

The finding that sense of family support is not significantly experienced by former drug users in the area of decision making bears 
some reflection. Since drug use is associated with weakness in life skills such as decision making (Bechara, 2005; Grant, Contoreggi, \& London, 2000), helping families of recovering drug users to engage in issues related to making decisions can further enhance their positive influence on their relatives' recovery process.

The particular link found between family support and reduction of SUD symptoms finds support in the literature (Daley, 2013). Engaging the family in the recovery process appears to be beneficial as families are given the opportunity to address the situation as a family and provide support towards recovery. Overall, the study shows how families of individuals in drug recovery are important resources to enhance recovery capital and lead to more favorable outcomes. They may have been part of the problem that led to drug use, but they are also a significant part of the solution.

\section{Recommendations for Research and Practice}

The study has limitations in terms of generalizability and scope. The study was a nonexperimental study which limits inferences of causality. Further investigation may be needed to evaluate family interventions using more stringent research designs to control for confounding variables. Convenience and purposive sampling were utilized, which limits generalizability. The conditions in the community, such as availability of potential participants and safety concerns were some barriers to data collection. The data from the interviews came from different perspectives of different family members. Future studies may wish to focus on a specific type of family member, such as the spouse or child of the participant.

Drug use and recovery is currently a controversial area for research and practice. The study is embedded within the bigger KKDK research project engaged in assisting LGUs with implementation of their community-based drug recovery program. These endeavors pose inherent and emerging challenges, related to politics, safety concerns, and other ethical considerations.

To further clarify aspects of the family sessions that are helpful to generating a sense of being supported and bringing about changes in quality of family interaction and capacity to resist relapsing into 
drug use, succeeding KKDK family sessions should make space for interviews with family members and the drug users themselves with regards to what aspects of their experience in the family workshops are most helpful in bringing about noted changes in the study.

The study points to the importance of culture in identifying protective and hindering factors to relapse of recovering relatives. Spirituality and recovery is an area of research that calls for closer study. The challenge of helping families support their recovering relatives to deal with issues related to decision making without violating personal boundaries and encouraging enmeshment also needs closer attention.

The study only focused on data immediately after the program. A basic challenge is how to sustain the initial changes that were observed through this program. The family modules did not promise healing to occur immediately even as they were guided on how to plan for ways to achieve their family goals. A follow-through study after six to 12 months is suggested to identify recovering users' progress and setbacks.

An aftercare family intervention and counseling program should ideally be in place to support the continuing or evolving needs of affected families. Since local resources are limited, a peer counseling program in the community could be an option. This means informal support may be extended by neighbors or support activities may be initiated by an association of recovering KKDK alumni. The outcome of the KKDK is certainly empowering among families because of the experience of positive changes as well as new knowledge and skills that were acquired. The engagement of these families in future programs assures better success in spite of challenges such as availability and scheduling, because they have felt and seen the immediate outcomes of this intervention.

\section{AUTHORS' NOTES}

This study was funded by the Commission on Higher Education K-12 Dare to Research Grant. 


\section{REFERENCES}

Alampay, L. P., Lachman, J. M., Landoy, B. V. L., Madrid, B. J., Ward, C. L., Hutchings, J., . . . Gardner, F. (2018). Preventing child maltreatment in low- and middle-income countries: Parenting for lifelong health in the Philippines. In S. Verma \& A. Petersen (Eds.), Developmental science and sustainable development goals for children and youth (pp. 277-293). Cham: Springer. doi:10.1007/978-3-319-96592-5_15

Almazan, J. U., Cruz, J. P., Alamri, M. S., Alotaibi, J. S. M., Albougami, A. S., Gravoso, R., . . Bishwajit, G. (2018). Predicting patterns of disaster-related resiliency among older adult Typhoon Haiyan survivors. Geriatric Nursing, 39(6), 629-634.

Bechara, A. (2005). Decision making, impulse control and loss of willpower to resist drugs: A neurocognitive perspective. Nature Neuroscience, 8(11), 1458.

Boterhoven de Haan, K. L., Hafekost, J., Lawrence, D., Sawyer, M. G., \& Zubrick, S. R. (2015). Reliability and validity of a short version of the General Functioning Subscale of the McMaster Family Assessment Device. Family Process, 54(1), 116-123. doi:10.1111/ famp.12113

Braun, V., \& Clarke, V. (2006). Using thematic analysis in psychology. Qualitative Research in Psychology, 3(2), 77-101.

Carter, B., \& McGoldrick, M. (1999). The expanded family life cycle: Individual, family, and social perspectives (3rd ed.). Needham Heights, MA: Allyn \& Bacon.

Clark, R. E. (2001). Family support and substance use outcomes for persons with mental illness and substance use disorders. Schizophrenia Bulletin, 27(1), 93.

Coleman, S. B., \& Davis, D. I. (1978). Family therapy and drug abuse: A national survey. Family Process, 17(1), 21-29. doi:10.1111/j.15455300.1978.00021.x

Copello, A. G., Velleman, R. D., \& Templeton, L. J. (2005). Family interventions in the treatment of alcohol and drug problems. Drug Alcohol Rev, 24, 369-385. doi:10.1080/09595230500302356

Creswell, J. W. (2009). Research design: Qualitative, quantitative, and mixed methods approaches (3rd ed.). Thousand Oaks, CA: 
Sage Publications.

Daley, D. C. (2013). Family and social aspects of substance use disorders and treatment. Journal of Food and Drug Analysis, 21(4), S73-S76. doi:10.1016/j.jfda.2013.09.038

Edralin, D. M. (2012). Innovative work-life balance strategies of Filipina entrepreneurs: New evidence from survey and case research approaches. Procedia-Social and Behavioral Sciences, 57, 201208.

Epstein, N. B., Baldwin, L. M., \& Bishop, D. S. (1983). The McMaster family assessment device. Journal of Marital and Family Therapy, 9(2), 171-180.

Epstein, N. B., Bishop, D. S., \& Levin, S. (1978). The McMaster model of family functioning. Journal of Marital and Family Therapy, 4(4), 19-31.

Grant, S., Contoreggi, C., \& London, E. D. (2000). Drug abusers show impaired performance in a laboratory test of decision making. Neuropsychologia, 38(8), 1180-1187.

Gruber, K. J., \& Taylor, M. F. (2006). A family perspective for substance abuse: Implications from the literature. Journal of Social Work Practice in the Addictions, 6(1-2), 1-29. doi:10.1300/ J160vo6no1_01

Guabong, J. U., Longno, D. G. , Castro, K. P., \& Guinto, E.M. (2016). The journey of drug dependents towards recovery. International Journal of Social Science Studies, 4(2), 108-113. doi:10.11114/ ijsss.v4i2.1266

Hechanova, M. R. M., Alianan, A. S., Calleja, M. T., Acosta, A., Villasanta, A., \& Yusay, C. (2019). The evaluation of the training and pilot implementation of Katatagan Kontra Droga sa Komunidad. Philippine Journal of Psychology, 52(1), 65-101.

Hechanova, M. R. M., Alianan, A. S., Calleja, M. T., Melgar, I. E., Acosta, A., Villasanta, A., .. \& \& Canoy, N. (2018). The development of a community-based drug intervention for Filipino drug users. Journal of Pacific Rim Psychology, 12, E12. doi:10.1017/ prp.2017.23

Hechanova, M., Waelde, L., \& Ramos, P. (2016). Evaluation of a groupbased resilience intervention for Typhooon Haiyan survivors. Journal of Pacific Rim Psychology, 10, E12. doi:10.1017/ 
prp.2016.9

Hosseinbor, M., Bakhshani, N. M., \& Shakiba, M. (2012). Family functioning of addicted and non-addicted individuals: A comparative study. International Journal of High Risk Behaviors \& Addiction, 1(3), 109-114. doi:10.5812/ijhrba.7514.

Ibrahim, F., \& Kumar, N. (2009). Factors effecting drug relapse in Malaysia: An empirical evidence. Asian Social Science, 5(12), 3744.

Jêdrzejczak, M. (2005). Family and environmental factors of drug addiction among young recruits. Military Medicine, 17o(8), 688.

Kabacoff, R. I., Miller, I. W., Bishop, D. S., Epstein, N. B., \& Keitner, G. I. (1990). A psychometric study of the McMaster Family Assessment Device in psychiatric, medical, and nonclinical samples. Journal of Family Psychology, 3(4), 431-439. doi:10.1037/hoo80547.

Lander, L., Howsare, J., \& Byrne, M. (2013). The impact of substance use disorders on families and children: From theory to practice. Social Work in Public Health, 28(3-4), 194-205. doi:10.1080/193 71918.2013.759005

Larner, G. (2004). Family therapy and the politics of evidence. Journal of Family Therapy, 26(1), 17-39.

Lavee, Y., \& Altus, D. (2001). Family relationships as a predictor of post-treatment drug abuse relapse: A follow-up study of drug addicts and their spouses. Contemporary Family Therapy, 23(4), 513-530.

Lewis, R. A., Piercy, F. P., Sprenkle, D. H., \& Trepper, T. S. (1990). Family-based interventions for helping drug-abusing adolescents. Journal of Adolescent Research, 5(1), 82-95.

Miralao, V. A. (1997). The family, traditional values and the sociocultural transformation of Philippine society. Philippine Sociological Review, 45(1/4), 189-215.

Psychological Association of the Philippines. (2017). Katatagan Kontra Droga sa Komunidad: A community-based drug recovery program. Quezon City: PAP.

Rebello, T. J., Marques, A., Gureje, O., \& Pike, K. M. (2014). Innovative strategies for closing the mental health treatment gap globally. Current Opinion in Psychiatry, 27 (4), 308-314.

Rowe, C. L. (2012). Family therapy for drug abuse: Review and updates 
2003-2010. Journal of Marital and Family Therapy, 38(1), 5981. doi:10.1111/j.1752-0606.2011.00280.x

Skewes, M. C., \& Gonzales, V. M. (2013). The biopsychosocial model of addiction. Principles of Addiction, 1, 61-70. doi:10.1016/B978-012-398336-7.00006-1

Stanton, M. D., \& Shadish, W. R. (1997). Outcome, attrition, and family-couples treatment for drug abuse: A meta-analysis and review of the controlled, comparative studies. Psychological Bulletin, 122(2), 170-191. doi:10.1037/0033-2909.122.2.170.

Szapocznik, J., Rio, A., Murray, E., Cohen, R., Scopetta, M., RivasVazquez, A., . . Kurtines, W. (1989). Structural family versus psych.odynamic child therapy for problematic Hispanic boys. Journal of Consulting and Clinical Psychology, 57(5), 571-8.

Tuliao, A. P., \& Liwag, M. D. (2011). Predictors of relapse in Filipino male methamphetamine users: A mixed methods approach. Journal of Ethnicity in Substance Abuse, 10(2), 162179. doi:10.1080/15332640.2011.573319

Turliuc, M. N., Ciudin, M., \& Roby, V. (2016). Psychometric properties of a short version of the family assessment device. Romanian Journal of Experimental Applied Psychology, 7(3), 10-25. doi:10.15303/rjeap.2016.v7i3.a2.

Vaughan, K., Kok, M. C., Witter, S., \& Dieleman, M. (2015). Costs and cost-effectiveness of community health workers: Evidence from a literature review. Human Resources for Health, 13(1), 1-16. doi:10.1186/s12960-015-0070-y

Velleman, R. D., Templeton, L. J., \& Copello, A. G. (2005). The role of the family in preventing and intervening with substance use and misuse: A comprehensive review of family interventions, with a focus on young people. Drug and Alcohol Review, 24(2), 93-109.

Yusay, C. C., \& Canoy, N. A. (2019). Healing the hurt amid the drug war: Narratives of young urban poor Filipinos in recovering families with parental drug use. International Journal of Drug Policy, 68, 124-131. doi:10.1016/j.drugpo.2018.10.009

Zimet, G. D., Dahlem, N. W., Zimet, S. G., \& Farley, G. K. (1988). The Multidimensional Scale of Perceived Social Support. Journal of Personality Assessment, 52(1), 30-41. 